University of Chicago Law School

Chicago Unbound

Public Law and Legal Theory Working Papers

Working Papers

2012

\title{
Unemployment and Regulatory Policy
}

Eric A. Posner

Jonathan Masur

Follow this and additional works at: https://chicagounbound.uchicago.edu/public_law_and_legal_theory

Part of the Law Commons

Chicago Unbound includes both works in progress and final versions of articles. Please be aware that a more recent version of this article may be available on Chicago Unbound, SSRN or elsewhere.

\section{Recommended Citation}

Eric Posner \& Jonathan Masur, "Unemployment and Regulatory Policy" (University of Chicago Public Law \& Legal Theory Working Paper No. 412, 2012).

This Working Paper is brought to you for free and open access by the Working Papers at Chicago Unbound. It has been accepted for inclusion in Public Law and Legal Theory Working Papers by an authorized administrator of Chicago Unbound. For more information, please contact unbound@law.uchicago.edu. 


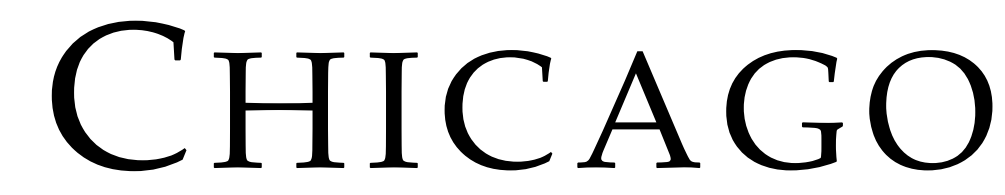

INSTITUTE FOR LAW AND ECONOMICS WORKING PAPER NO. 625

(2D SERIES)

Public LaW AND Legal Theory Working PAPer No. 412

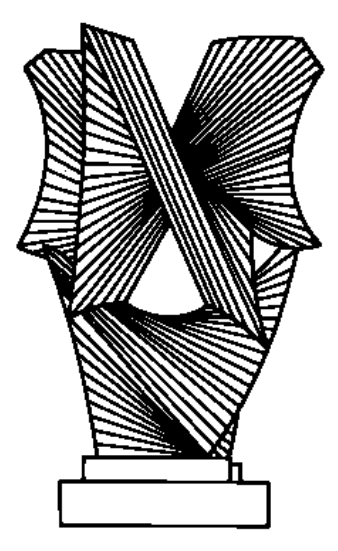

UNEMPLOYMENT AND REGULATORY POLICY

Jonathan S. Masur and Eric A. Posner

\section{THE LAW SCHOOL THE UNIVERSITY OF CHICAGO}

December 2012

This paper can be downloaded without charge at the Institute for Law and Economics Working Paper Series: http://www.law.uchicago.edu/Lawecon/index.html and at the Public Law and Legal Theory Working Paper Series: http://www.law.uchicago.edu/academics/publiclaw/index.html and The Social Science Research Network Electronic Paper Collection. 


\title{
Unemployment and Regulatory Policy
}

\author{
Jonathan S. Masur and Eric A. Posner
}

December 9, 2012

Introduction $^{1}$

Unemployment is generally thought to be a problem that is best addressed with fiscal and monetary policy, not with regulations. But regulatory agencies have long tried to calculate and respond to the possible unemployment effects of regulations. Some statutes require agencies to use so-called feasibility analysis, according to which the agencies should regulate up until there is significant job loss (Masur and Posner 2010).Even when statutes do not contain this requirement, the Obama administration has asked agencies to do what we have called "job loss" analysis, under which agencies estimate the unemployment effects of proposed regulations and disregard regulations that would cause excessive job loss. The job loss analysis is conducted separately from a cost-benefit analysis, which the regulation must also pass. In our article, Regulation, Unemployment, and Cost-Benefit Analysis, we argued that regulatory agencies should incorporate the costs of unemployment into cost-benefit analyses of proposed regulations (Masur and Posner, 2012).We argued that feasibility analysis and job loss analysis make little sense because they do not specify the threshold at which job loss is excessive, and do not explicitly make tradeoffs between unemployment effects and social gains.

The article appeared at a politically contentious time. Republicans had been arguing that regulation causes unemployment and blamed the high rate of unemployment at that time on the Obama administration's regulatory agenda. They proposed a bill that would ban new regulation when the unemployment rate exceeds 6 percent. ${ }^{2}$ Our paper received some modest media attention $^{3}$ and was cited in the 2012 draft OMB report, which sought advice from commentators

\footnotetext{
${ }^{1}$ Authors' Note: The authors would like to thank Cary Coglianese, Adam Finkel, Howard Chang, Shi-Ling Hsu, William Hubbard, Prasad Krishnamurthy, Michael Livermore, Tom Miles, Jonathan Nash, Paul Noe, Arden Rowell, and participants in the University of Pennsylvania Law School's conference on Regulation's Impact on Jobs for helpful comments on earlier drafts. This research was funded in part by the David and Celia Hilliard Fund.

2 H.R. 4708, Regulatory Freeze for Jobs Act of 2012, at http://www.gpo.gov/fdsys/pkg/CPRT112HPRT75053/pdf/CPRT-112HPRT75053.pdf.

${ }^{3}$ Economist 2011.
} 
as to whether cost-benefit analysis should incorporate unemployment costs and, if so, how it should do so. ${ }^{4}$

This chapter proceeds in three parts. Part I briefly recapitulates our earlier argument. In Part II, we respond to some important questions and critiques that commentators have offered in response to our paper. Part III discusses some broader issues raised by the debate about the incorporation of unemployment costs into cost-benefit analysis, including the role of "secondorder" or remote costs and benefits and the treatment of the ex ante incentives of regulation.

\section{I.A Recapitulation}

When regulators conduct cost-benefit analysis, they typically compare the benefits of a proposed regulation and the compliance costs. On the usual understanding of cost-benefit analysis, compliance costs are borne by shareholders and consumers. If the firm can pass on the costs to consumers in the form of higher prices, it will do so. If not, shareholders will see a reduction in profits. If compliance costs force the firm to reduce production and lay off workers, then the workers will normally suffer losses as well. While unemployed, they will lose whatever surplus they enjoyed while working; they may incur search costs; and, if industry-specific human capital accounted for some of their wages, and they cannot find a job in the same industry, then they will suffer the destruction of some of their human capital.

Economists have generally ignored the losses to workers, probably because they assume the losses will be small relative to the major costs and benefits of the regulation. But recent empirical work suggests that the loss to each worker who becomes unemployed may be large. The most likely explanation is that industry- (or firm-) specific human capital accounts for a large portion of wages in many regulated industries.

The lost human capital of workers should be counted in any cost-benefit analysis just as the loss of physical assets. From a normative standpoint, there is no reason to prefer a regulation that causes a machine to lose its value because its output can no longer be marketed to a regulation that causes a worker's skills to lose their value because the output that depends on those skills can no longer be marketed. To account for the loss to workers, cost-benefit analysis should incorporate the loss of human capital — which can be roughly approximated as the difference between the wage that the worker earns in his original position and the wage that he earns in the next-best position outside the industry (or outside of a position that requires that human capital).

In our earlier work we also estimated the social costs of lost jobs. Workers who are laid off lose an average of $\$ 100,000$ in wages over the course of their lifetimes. These wage losses could simply reflect that the employee was being paid above-market wages in her previous job, in which case their loss does not represent a true social cost. But they could also represent the

\footnotetext{
${ }^{4}$ Office of Management and Budget 2012.
} 
loss of firm- or industry-specific capital, and thus the loss of employee productivity. In such a case, the wage losses would be genuine social costs. Regardless of the loss of wages, unemployment also carries with it significant hedonic and transition costs. Workers who lose their jobs typically suffer substantial hedonic penalties - the loss of a great deal of happinessthat persists even after they have found new employment. They are also more likely to suffer a variety of health problems and to die earlier, even controlling for their lower income. In addition, when a worker is laid off she must often bear significant costs in the process of finding new employment. These include the costs of searching for a new job, re-training costs, and the costs of moving to a new location. Finally, the worker's dependents typically suffer costs and losses from the worker's unemployment. None of these types of costs have ever been included in standard CBA.

In many instances, the inclusion of unemployment costs will not (and should not) alter a regulatory decision. For instance, in recent work Reed Walker (2011: 28) calculates that the Clean Air Act created unemployment-related costs of approximately $\$ 9$ billion. Compared with benefits estimated to be between $\$ 160$ billion and \$1.6 trillion (Walker 2011: 28), these additional costs do not seem terribly significant. However, including unemployment costs in CBA could nonetheless affect the outcome of many regulatory analyses. In our article, we conservatively estimated the costs of unemployment at $\$ 100,000$ per worker over the worker's lifetime, or slightly more than $\$ 3,000$ per year. (Regulation that leads to greater employment would produce equally significant benefits.) We then recalculated CBA, performed by EPA, on a regulation limiting the use of chlorinated compounds in the pulp and paper industries, to include the costs of unemployment. PA projected that the regulation would create $\$ 159.5$ million in net lifetime benefits but would also result in more than 5,711 lost jobs, a fact that EPA calculated and acknowledged but did not include in its CBA. Recalculating the cost-benefit analysis to include the costs of these lost jobs reduces the lifetime net benefits of the regulation from $\$ 159.5$ million to $-\$ 411.6$ million. This does not necessarily mean that the agency should not have regulated at all. But it suggests that the agency should have considered a less stringent regulation, one that would produce smaller benefits but would also have led to less unemployment.

\section{Objections}

\section{A. The Double-Counting Problem}

David Driesen (2012) argues that our approach would involve counting the costs to workers twice. Driesen correctly notes that when agencies calculate the costs of regulation, they look at the firm's compliance cost and do not consider how those costs are distributed. For example, suppose that it costs a firm $\$ 100,000$ to comply with a new regulation. The firm dictates how that cost is distributed. If demand for the firm's product is inelastic, the firm will pass on the cost to consumers. If not, the firm will either cut dividends or reduce wages (or fire 
workers).It is possible that the firm will simply fire a worker whose wage is $\$ 100,000$.If the worker does not obtain a new job, then the worker bears the full cost of the regulation. Thus, it would be wrong to add the $\$ 100,000$ cost to the worker to the $\$ 100,000$ compliance cost.

This analysis is incorrect. To see why, observe that if a firm fires a worker who earns $\$ 100,000$, the firm will not actually save $\$ 100,000$. That would be the case only if the worker earns $\$ 0$ of revenue for the firm; but if that were true, the firm would have fired the worker long before the regulation was issued. Firms employ workers only when their value is greater than their cost; thus, firing a worker would not enable the firm to raise funds to finance compliance costs, as Driesen argues, but instead put the firm even farther in the hole. Put another way, Driesen assumes a world in which the firm fires a worker earning $\$ 100,000$ and nothing else changes. But this worker must have been producing something for the firm, or else the worker would have been fired long ago. This lost productivity is precisely the social cost that can accompany regulation-induced unemployment. Driesen confuses accounting costs and economic costs. By assuming away the loss of production, Driesen assumes away the social cost we seek to measure.

Inefficient Industries and the Buggy Whip Factory Problem

Another objection is that, if our analysis is correct, it would be proper to refrain from regulating (or fully regulating) industries that produce net social costs because of harmful externalities. Imagine a coal-fired power plant that produces a great deal of pollution. Assume that the negative externality is greater than the compliance cost, which we will assume will be taken out of consumer surplus - so that the factory produces energy whose social value to consumers is less than the social loss from pollution. Meanwhile, a number of workers have industry-specific skills; if the plant is shut down, they will lose their jobs and earn lower wages in other industries. Should the lower wages make a difference to regulatory analysis?

To make the answer as clear as possible, suppose that the negative externality is worth 100 , the cost of compliance is 90 (and hence the consumer's surplus, as we assume), and the loss to the workers is $20 .{ }^{5}$ In addition, imagine a second firm that uses robots instead of workers. Those robots are worth 20 but would lose their value if the regulation is issued. But if that is true, then compliance costs go up to 110 , and the regulation would fail a cost-benefit analysis. The same point can be made about the firm with workers. The difference is that the workers enjoy the value of their human capital (which they recover in the form of a wage premium), while the firm enjoys the value of the robots. There is no reason to treat the cases differently, but that would be the result if unemployment costs are not incorporated into cost-benefit analysis.

\footnotetext{
${ }^{5}$ As we noted in Masur and Posner (2012) and describe here as well, the loss to the workers is measured by taking their current market wage and subtracting the market wage that they will earn in their next job and any transition costs (moving costs, retraining costs, etc.).In Masur and Posner (2012) we conservatively estimated that amount at $\$ 100,000$ per worker over the worker's lifetime.
} 
The odd-seeming result is that regulators would refrain from issuing a regulation that prevents a coal power plant from spewing out pollution where the cost of the pollution is greater than the value of the electricity for consumers, just in order that the power plant workers continue to hold jobs that do not seem to be socially productive. But this impression that the jobs are not socially productive is an artifice of the way in which standard CBA counts costs. The coal is not valueless; it provides electric power. Some of the value of that power is captured by consumers, some by the owner of the power plant, and some by the workers. Failing to count the benefits captured by the workers results in undercounting the overall benefits. From an economic perspective, the factory should remain open because the net social benefits are positive, and it is arbitrary how those benefits are distributed among workers, consumers, and shareholders.

A skeptic might then wonder whether the same analysis that we apply here to regulation should be applied to market-based unemployment as well. For instance, prior to the invention of the automobile, some workers made a living producing buggy whips. This production was socially beneficial until the automobile was invented and demand for buggy whips collapsed. Should the government have propped up buggy whip producers in order to avoid unemployment in that industry? The answer is that it should not have. If the market is functioning properly, the fact that buggy whip factories close and buggy whip manufacturers are laid off indicates that the social costs of producing buggy whips exceed the social benefits. There is no surplus to divide between consumers and producers. If there were some surplus, consumers, shareholders, and workers would negotiate some division of the surplus. The price of buggy whips might fall, returns to buggy whip shareholders might fall, and wages might fall as well, but buggy whips would continue to be produced. A well-functioning market is the mechanism that determines whether an activity produces net social benefits or costs. No cost-benefit test is necessary; the market itself performs this test. This is the reason that cost-benefit analysis is necessary when the government regulates: the regulation is standing in as a corrective to a poorly-functioning market, and thus the market itself cannot perform the cost-benefit test.

Thus far we have only been discussing traditional command-and-control regulation, in which government mandates that firms install a particular safety device, or discontinue use of a hazardous chemical, or even shut down entirely. There are alternatives to this type of regulation, including the imposition of Pigouvian taxes. ${ }^{6}$ A Pigouvian tax is designed to correct a market failure by forcing some actor to internalize a cost that it is creating. It thus replicates a wellfunctioning market by forcing this actor to account for all of its externalities. Accordingly, CBA is not necessary - and thus unemployment costs are irrelevant - when the government imposes a Pigouvian tax for the same reasons that it is unnecessary when a market is functioning properly. That is, imagine a firm that creates an externality of 10 per unit of a good that it produces. Before the government bans production of the good (via command-and-control regulation) it should conduct a CBA to determine whether such a ban would be cost-benefit justified. But if the

\footnotetext{
${ }^{6}$ We thank Howard Chang for raising this issue.
} 
government instead simply imposed a Pigouvian tax of 10 on each unit of that good, thereby forcing the producers and consumers of the good to internalize the externality, it would not need to conduct a Cabin the market for the good is otherwise efficient, the good will be produced and consumed in optimal amounts once there are no externalities.

Should unemployment costs be calculated in determining the Pigouvian tax itself? The answer is no. Once the firm is forced by the tax to internalize its externalities, it will make the proper decision whether to continue to produce (and how much), taking into account the benefits from production for consumers, shareholders, and workers. The difference between cost-benefit analysis and the Pigouvian tax is that cost-benefit analysis takes into account the costs to the firm, not just the benefits to third parties, and those costs include potential costs to workers, as well as to shareholders and consumers. When the government calculates a Pigouvian tax, it must ignore all of those costs.

\section{Wages: Rents versus Returns}

Another question we have received is whether wage losses incurred by workers would not be recovered by shareholders in the form of higher profits or consumers in the form of lower prices, in which case there is no social loss. If that is the case, then wage losses incurred by workers should not play a role in cost-benefit analysis.

The answer is that the wage loss is a social loss only if the worker was earning a wage premium because of human capital — and thus because of his productivity—rather than because the worker was capturing rents. The most common source of such rents is the union wage premium. If unionized workers receive above-market wages of say $\$ 110$, lose their jobs as a result of regulation, and then obtain identical or similar non-unionized jobs that pay $\$ 100$, then it would be wrong to include the $\$ 10$ wage loss in the cost-benefit analysis. The regulation is simply eliminating the union, putting downward pressure on wages until they reach market levels. In some cases the affected workers may have no specialized skills. For instance, if a unionized steel mill is forced to close, there will be some workers whose skills have nothing to do with steel manufacturing - accountants, to name one example - who will be laid off. These workers possess no industry- or firm-specific skills and can find new jobs in a variety of other industries. If they take non-unionized accountant jobs in high-tech chip factories, their wages might decrease. But this decrease would not represent a social loss.

However, as we discuss in Masur and Posner (2012), the empirical literature so far suggests that long-term wage losses endured by many workers cannot be attributed for the most part to the loss of rents, leaving the loss of human capital as the most likely explanation. In any event, the regulator would need to take this account, although this has the politically sensitive implication that regulators would count wage losses in unionized industries less than wage losses in non-unionized industries when conducting the cost-benefit analysis. 
This implicates a broader point about what CBA is really measuring when it counts wage losses. The socially valuable aspect of employment is not the wage paid by the firm to the employee - that is just a transfer. Rather, it is the worker's productivity that is socially valuable. If a skilled worker who had been trained to make steel can no longer find work in a steel mill, that worker's potential productivity has been lost. If the steel worker can only find a job flipping burgers at McDonald's, the lost productivity is the difference between the value of the individual's work in the steel mill and the value of the work at McDonald's. This is why we describe the loss as a loss of human capital. The worker's human capital - the skills that she has acquired, the education and training that she has received - are what create the potential for her to be a productive steel worker.

There is no "direct" measure of the worker's lost productivity; the only way to measure the value of the productivity is to calculate what it is worth in the market. This is why it is the worker's market wage that matters for Cabin a competitive marketplace workers will be paid the value of their productivity, and thus the wage loss that results from unemployment will be the clearest measure of the lost productivity. If workers are earning above-market rents, then they are earning wages in excess of their productivity. It would overstate the social loss from unemployment if CBA were to count their entire wage loss on the cost side of the ledger. ${ }^{7}$

\section{Broader Issues in Cost-Benefit Methodology}

Our argument for counting unemployment costs in CBA raises larger questions about the methodological choices that underlie textbook cost-benefit analysis. Two issues are of particular importance. First, CBA has traditionally drawn a line between "first-order" and "second-order" costs and benefits, calculating the former and largely eschewing the latter. Second, CBA is predominantly an ex post analysis, rather than an ex ante one, in the sense that it takes all economic activity preceding the regulation as given and asks only whether the regulation will produce net costs or benefits. That is, CBA examines whether a regulation will improve welfare from the status quo, not whether that regulation would create efficient ex ante incentives for parties to anticipate regulation and prepare accordingly. We suggest here that it might be time to reconsider these methodological choices. There is no principled distinction between first- and second-order costs and benefits, and CBA should not make distinctions on that basis. More speculatively, policymakers should consider reformulating CBA to take greater account of ex ante incentives and pay less attention to ex post benefits and costs. Such a move could result in increased welfare over the long term.

\footnotetext{
${ }^{7}$ We note that the above discussion centers principally around the costs of unemployment generated by lost productivity.In addition, as we explained in our article, there may be significant transition costs as unemployed workers are forced to search for new employment, seek job training and education, or move to another location in search of a job.These costs have nothing to do with the wages that the workers were previously earning, and so they are separate from the discussion above.
} 


\section{A. First- and Second-Order Costs}

Any type of regulation will produce some number of initial consequences followed by a potentially infinite set of subsequent ripple effects. Consider the Department of Transportation's recent regulation raising fuel economy standards for automobiles and light trucks. The regulation described will, at the outset, force automobile manufacturers to produce more fuel-efficient automobiles. Consumers will pay more for these cars, but they will also consume less gasoline per mile driven, making it less expensive to operate the vehicles.

These are the most direct consequences of the regulation, but they are hardly the only ones. Consumers will also purchase fewer cars because of the higher price, which will lead to unemployment as car manufacturers lay off excess workers. At the same time, the need for more fuel-efficient engines may lead to economic development and job growth in industries related to engine technology. The higher price of automobiles may lead some consumers to shift away from driving and towards public transportation. Other consumers who can still afford cars might find driving less expensive than before (because of their improved fuel economy) and choose to drive more. The Department of Transportation estimated that there would be fewer cars on the road, but that the cars that remained would be driven more miles. ${ }^{8}$ DOT believed that the total number of automobile-miles driven would increase, and this in turn would increase automobile fatalities and delays due to roadway congestion. Every additional roadside fatality created (or avoided) will also have direct effects upon the families of the victims, and so forth. For that matter, increases or decreases in the demand for gasoline among American drivers might affect the price of gasoline, the rate of global warming, or even American foreign policy, all of which could itself produce a variety of tertiary effects.

Most of these hypothetical ramifications are what might be called "second-order" effects of the regulation (Institute for Policy Integrity 2012:10). This is to distinguish them from what one might describe as the regulation's "primary" effects: the costs of improving fuel economy and the reduction in automobile operating costs. As a general matter, CBA does not attempt to account for second-order effects (Baram et al., 1998:19), though there are notable exceptions to that rule. For instance, the CBA that accompanied the DOT's fuel economy rule included an analysis of a variety of that regulations effect's including the regulation's impact on global climate change, as we discussed at length in earlier work (Masur and Posner 2011).Several commentators have suggested to us that it is inconsistent to advocate including unemployment costs in CBA without similarly incorporating all other "second-order" costs and benefits.

At the outset, it is worth noting the slippery nature of these categories. If we think of a regulation's compliance cost as reducing the joint surplus that consumers and producers share, then unemployment costs are just one manifestation of the reduction in producer surplus — part of

\footnotetext{
${ }^{8}$ Average Fuel Economy Standards Passenger Cars and Light Trucks Model Year 2011, 74 Fed. Reg. 14,196, 14,412 (Mar. 30, 2009) (codified at 49 C.F.R. pts. 523, 531, 533, 534, 536 and 537).
} 
the overall compliance cost. Most practitioners of CBA would classify this as a "first-order" cost. On the other hand, the causal chain that leads from regulation to unemployment involves a number of steps. Regulation makes a product more expensive to produce; elasticity in the market for that product causes the product's price to rise; that rise in price reduces the quantity of that product that consumers will purchase; the reduction in quantity causes firms to produce less; the drop in production renders some of the firm's workers irrelevant; and the firm responds by firing those workers. Accordingly, many commentators would consider unemployment costs a secondorder (or third-order) effect. We need not wrestle this question to the ground, however, because we do not believe that there is any conceptual importance to these categories. There is nothing magical about the number of causal steps between a regulation and its effect. Policymakers must find some other principle to separate those costs and benefits that should be calculated and included in CBA from those that should not.

This problem is common to several areas of law. Any tortious act or breach of contract can create an extended series of secondary and tertiary effects. For example, a driver who runs his car into a pedestrian will not only injure the pedestrian, forcing the pedestrian to incur medical costs, but also cause the pedestrian to miss work, which may put a greater burden on his colleagues or cause the employer to lose profits, and also affect family members in various ways, and possibly their work and relationships with other people. The accident might use emergency personnel who are then unable to rescue someone else. And so on. Faced with the need to draw some line, tort and contract law usually address this problem by holding the tortfeasor or the breaching party responsible only for the direct and foreseeable effects of her action. ${ }^{9}$ The theory behind this approach in tort and contracts is threefold: a) it is only fair to hold a party responsible for the foreseeable consequences of her actions; b) it is impossible to give individuals incentives to take precautions against unforeseeable harms; and c) unforeseeable harms are likely to be significantly smaller and harder to measure than direct harms (Posner 2007:1936), or they may be offset by benefits, ${ }^{10}$ so that including them will create excessive error costs. ${ }^{11}$

The first two of these rationales do not apply to cost-benefit analysis, which is not concerned with individual responsibility or with ex ante incentives (more on that point later).Instead, CBA practitioners have largely seized on the third rationale: that second-order costs and benefits are much smaller and more difficult to measure (Baram et al. 1998:19; Goldberg and Epstein 2005:511). This may be true as a general matter, but there are a number of "second-order" costs and benefits that could be large enough to alter the outcome of a cost-

\footnotetext{
${ }^{9}$ Restatement (Second) of Contracts $\S 351$ (1) (1981) ("Damages are not recoverable for loss that the party in breach did not have reason to foresee as a probable result of the breach when the contract was made"); Wood v. Foremost Ins. Co., 477 F.3d 1027, 1029 (8th Cir. 2007); Dillon v. Legg, 68 Cal. 2d 728, 739 (1968).

${ }^{10}$ This is illustrated by the economic loss rule, which does not allow businesses that lose profits from a tort to collect damages for those lost profits. The theory is that the "lost" customers will patronize other businesses, so there is no or little net economic loss.

${ }^{11}$ Lawson v. Safeway Inc., 191 Cal. App. 4th 400, 417, 119 Cal. Rptr. 3d 366, 379 (2010); Palsgraf v. Long Island R. Co., 248 N.Y. 339, 345, 162 N.E. 99 (1928).
} 
benefit analysis in a variety of regulations. We demonstrated this with respect to reductions in carbon outputs and climate change (Masur and Posner 2011) and then unemployment (Masur and Posner 2012). ${ }^{12}$

It is not enough, then, for CBA to declare that certain costs and benefits are "secondorder" and ignore them. Nor should CBA incorporate second-order costs and benefits on an ad hoc basis, randomly including some but not others. Rather, practitioners of CBA should be guided entirely by pragmatic concerns: 1) is a particular cost or benefit projected to be relatively large in comparison with the overall net costs and benefits to the regulation; and 2) can that cost or benefit be measured with any degree of accuracy? When the answer to both questions is "yes," as it is with respect to unemployment, CBA should measure and include the cost or benefit within the overall calculation.

\section{B. Ex Post versus Ex Ante}

Underlying the debate regarding unemployment and other second-order costs is the fact that CBA is fundamentally an ex post procedure, rather than an ex ante one. That is, CBA asks whether, under current conditions, a regulation or project will produce net benefits or net costs. It is not designed to create correct ex ante incentives. When a regulator uses cost-benefit analysis to determine whether an industry excessively pollutes, it will usually not consider whether a regulation will have negative ex ante effects, for example, on the decision of people to live near factories (which increases the amount of harm).In other words, it may be better from the social standpoint for people not to move near dirty factories, in which case the pollution causes no harm, than for people to move near dirty factories which are then shut down by a regulator. Tort law addresses this incentive problem by depriving people who "come to the nuisance" of a remedy under certain circumstances, but cost-benefit analysis does not. In a similar vein, regulators often impose stricter regulations on new plants than on existing plants even though regulating existing plants could have desirable ex ante incentives on firms to anticipate future regulation. Indeed, firms may overinvest in plants in the hope that high compliance costs could block future regulation.

Similar points can be made about regulation that takes into account unemployment costs. It is socially beneficial when workers anticipate which industries will be most socially valuable in the future and seek employment and training in those industries. From the perspective of social welfare it might be preferable if a worker entering the labor force in 1995 sought training in the solar power industry rather than coal-generated power industry (to the extent that such

\footnotetext{
${ }^{12}$ The regulations we examined in our 2011 paper on the social cost of carbon did not cease to be cost-benefit justified under different carbon valuations (Masur and Posner 2011). Yet that does not mean that they were optimal, either.The larger point is that the mere fact that the benefits of a regulation will exceed the costs does not mean that an agency should promulgate precisely that regulation. Rather, agencies should search for regulations that maximize benefits net of costs, a point that Adam Finkel explores in greater detail in this volume.
} 
substitutions are possible).CBA does not attempt to create additional incentives, beyond those already generated by the market, for workers to make welfare-enhancing choices. It asks only whether a regulation or project would enhance welfare compared with the status quo, and the status quo already subsumes these types of individual decisions. But as a result workers might enter marginal industries, which, under our approach, may be saved rather than regulated out of existence.

In this sense, our approach takes CBA as a given; it was not our purpose to reconsider CBA's foundations. But this perverse result is a reminder that CBA is very much a second-best procedure. The task of generating efficient ex ante incentives might be too complicated for policymakers employing CBA. ${ }^{13}$ Yet it is worth at least considering whether cost-benefit analysis could be altered to focus on ex ante incentives as well as ex post consequences. A full-scale treatment of this subject is beyond the scope of this chapter, but one can imagine the general shape that a reformulated cost-benefit analysis would take. The crucial questions for regulators would be whether particular regulatory costs and benefits were foreseeable (that is, whether the cost of anticipating the regulation was less than social benefits) at an earlier point in time, and whether individuals and firms failed to anticipate the costs and benefits. If, for instance, a future regulatory cost was foreseeable and a firm failed to account for it, it may be that the cost should not be included in the cost-benefit calculation. Thus, cost-benefit analysis might accept the possibility of welfare-reducing regulation in the interest of incentivizing affected parties to take precautions ex ante due to the possibility of regulation. ${ }^{14}$

Suppose, for instance, that a firm must decide in 2012 whether to install a coal-fired power plant or a solar plant. The coal-fired plant will cost 100 and the solar plant will cost 120 , but suppose it is well understood that the coal-fired plant will create a negative externality worth 30 due to climate change. The firm is not yet required to internalize the climate change externality because carbon emissions are not regulated. But it is certainly foreseeable that coalfired power might eventually be banned if its costs exceed its benefits. Suppose that the firm installs the coal-fired plant, and twenty years later the EPA considers banning coal-burning power plants. It seems clear that firms should be prohibited from installing additional coal-fired plants because the costs of burning coal $(100+30)$ exceed the costs of using solar power $(120)$.

Should the EPA additionally close existing coal-burning plants and force firms to install solar in their place? The costs of doing so (120 - the cost to install a new solar plant) would seem to exceed the benefits (30).But perhaps policymakers should adopt an ex ante approach and refuse to include the cost of switching to solar in the cost-benefit analysis. After all, in our example the firm could have anticipated that the costs of coal power would exceed the benefits

\footnotetext{
${ }^{13}$ At a minimum it is important that CBA be impervious to strategic behavior on the part of potential targets of regulation.If CBA can easily be manipulated it is of little use to policy analysis. In earlier work (Masur and Posner 2012) we described why including unemployment costs would not expose cost-benefit analysis to significant strategic manipulation by regulated parties.

${ }^{14}$ We discussed a version of this point and noted its limitations in Masur and Posner (2012).
} 
and that coal might someday be regulated. Perpetuating the status quo by allowing the existing coal plant to continue operating would incentivize firms to ignore these costs ex ante. On the other hand, forcing the firm to switch to solar despite the fact that such a move is welfarediminishing might provide the firm with the proper ex ante incentivizes to install solar power in the first place. This would effectively align cost-benefit analysis with the literature on transition relief, which has counseled against grandfathering pre-existing harmful uses where doing so would diminish incentives for firms to anticipate legal change (Kaplow1986; Levmore 1999; Shavell 2008; Masur and Nash 2010).

The same analysis would apply to unemployment costs. Regulators would need to ask whether workers who enter an industry could foresee at reasonable cost that it would at a later time be optimal for the government to regulate the industry or increase the level of regulation so that the workers' industry-specific skills would lose their value. We suspect that, in the case of workers, the answer to this question will almost always be no; and so we do not see ex ante effects as posing a significant challenge to our proposal that standard CBA incorporate unemployment costs.

The literature on legal transitions and grandfathering is vast and raises significant questions that would need to be addressed before policymakers could consider adopting "ex ante"-style CBA wholesale. Among the many problems this approach would create is the difficulty in gauging which costs and benefits were foreseeable at some point in the past. Nonetheless, this very brief sketch should make clear that a cost-benefit methodology focused on ex ante incentives could function very differently than standard CBA and could conceivably produce greater social benefits in the long term.

\section{Conclusion}

Ultimately it is impossible to know in advance what impact unemployment costs will have upon regulatory decision-making. It may be that most regulations will resemble the Clean Air Act, in that the net benefits so far exceed the costs that unemployment costs represent little more than a rounding error. Or it may be that many regulations, like the EPA pulp and paper regulation we analyzed in prior work, will create sufficiently high unemployment costs that the agencies involved should consider less stringent regulation. It is even possible that existing "job loss analysis" overweights unemployment so that if unemployment costs were instead properly incorporated into cost-benefit analysis, stricter rather than weaker regulation would result. The only way to know for certain is for regulatory agencies to begin incorporating unemployment costs into their cost-benefit analyses as we have argued.

Moreover, unemployment costs are the canary in the cost-benefit analysis coal mine. For decades agencies have ignored what might be a significant source of costs (or, in some cases, benefits) on the assumption that they were at most second-order. That assumption has been proven false, at least in some cases. This raises the question of what other important "second- 
order" costs and benefits agencies have ignored and whether those costs and benefits might be substantial enough to affect regulatory outcomes. The benefits of reduced carbon emissions, which agencies only began to consider in 2009, are an example of such a benefit (Masur and Posner 2011).Agencies that conduct cost-benefit analysis should engage in a comprehensive search for such substantial but uncounted costs and benefits.

Even more generally, agencies should reconsider some of the assumptions that have underlain cost-benefit analysis from the beginning. Agencies might be capable of incentivizing private actors to anticipate efficient regulations (and adopt efficient behaviors earlier) by adjusting the way that they conduct cost-benefit analysis - for instance, by only counting certain costs and benefits. This would represent a substantial departure from traditional cost-benefit analysis, and perhaps it is ill-advised. But the weaknesses of cost-benefit analysis that we have already exposed suggest that further changes could be in order. 


\section{$\underline{\text { References }}$}

Driesen, David.(2012).Job Loss and the Incoherent Expansion of Cost-Benefit Analysis, http://works.bepress.com/context/david_driesen/article/1003/type/native/viewcontent.

Baram, Michael et al. (1998) "Transgenic Agriculture: Biosafety and International Trade," 4 Boston University Journal of Science \& Technology 4-51

The Economist (2011) "Clause and Effect: The Business Cycle Matters When Assessing the Cost of New Regulations," http://www.economist.com/node/21534767

Furman, Jason(2006) Center on Budget Policy and Priorities, "A Short Guide to Dynamic Scoring," http://www.cbpp.org/files/7-12-06bud2.pdf

Goldberg, Victor P. and Richard A. Epstein (2005) "Introductory Remarks: Some Reflections on TwoSided Markets and Pricing," 2005 Columbia Business Law Rev. 509-513

Institute for Policy Integrity (2012) "The Regulatory Red Herring: The Role of Job Impact Analyses in Environmental Policy Debates," http://policyintegrity.org/files/publications/Regulatory_Red_Herring.pdf

Kaplow, Louis (1986) "An Economic Analysis of Legal Transitions," 99 Harvard Law Review 509-617

Levmore, Saul (1999) “Changes, Anticipations, and Reparations,” 99 ColumbiaLaw Rev. 1657

Masur, Jonathan S. and Jonathan R. Nash (2010) “The Institutional Dynamics of Transition Relief,” 85 N.Y.U. Law Rev. 391

Masur, Jonathan S. and Eric A. Posner (2011) "Climate Regulation and the Limits of Cost-Benefit Analysis," 99 California Law Review 1557

Masur, Jonathan S. and Eric A. Posner (2012) "Regulation, Unemployment, and Cost-Benefit Analysis" 98 Virginia Law Review 579

Office of Management and Budget (2012) "Draft 2012 Report to Congress on the Benefits and Costs of Federal Regulations and Unfunded Mandates on State, Local, and Tribal Entities," http://www.whitehouse.gov/sites/default/files/omb/oira/draft_2012_cost_benefit_report.pdf

Posner, Eric A. (2007) "Climate Change and International Human Rights Litigation: A Critical Appraisal,” 155 University of Pennsylvania Law Rev. 1925-1945

Shavell, Steven (2008) "On Optimal Legal Change, Past Behavior, and Grandfathering," 37 J. Legal Studies 37

Walker, W. Reed (2011) "The Transitional Costs of Sectoral Reallocation: Evidence From the Clean Air Act and the Workforce" 
Readers with comments should address them to:

Professor Jonathan Masur

University of Chicago Law School

1111 East 60th Street

Chicago, IL 60637

jmasur@uchicago.edu 
Chicago Working Papers in Law and Economics

(Second Series)

For a listing of papers 1-599 please go to Working Papers at http://www.law.uchicago.edu/Lawecon/index.html

600. Joshua Elliott, Ian Foster, Sam Kortum, Gita Khun Jush, Todd Munson, and David Weisbach, Unilateral Carbon Taxes, Border Tax Adjustments, and Carbon Leakage, June 2012

601. David A. Weisbach, Should Environmental Taxes Be Precautionary? June 2012

602. Saul Levmore, Harmonization, Preferences, and the Calculus of Consent in Commercial and Other Law, June 2012

603. David S. Evans, Excessive Litigation by Business Users of Free Platform Services, June 2012

604. Ariel Porat, Mistake under the Common European Sales Law, June 2012

605. Stephen J. Choi, Mitu Gulati, and Eric A. Posner, The Dynamics of Contrat Evolution, June 2012

606. Eric A. Posner and David Weisbach, International Paretianism: A Defense, July 2012

607 Eric A. Posner, The Institutional Structure of Immigration Law, July 2012

608. Lior Jacob Strahilevitz, Absolute Preferences and Relative Preferences in Property Law, July 2012

609. Eric A. Posner and Alan O. Sykes, International Law and the Limits of Macroeconomic Cooperation, July 2012

610. M. Todd Henderson and Frederick Tung, Reverse Regulatory Arbitrage: An Auction Approach to Regulatory Assignments, August 2012

611. Joseph Isenbergh, Cliff Schmiff, August 2012

612. Tom Ginsburg and James Melton, Does De Jure Judicial Independence Really Matter? A Reevaluastion of Explanations for Judicial Independence, August 2012

613. M. Todd Henderson, Voice versus Exit in Health Care Policy, October 2012

614. Gary Becker, François Ewald, and Bernard Harcourt, "Becker on Ewald on Foucault on Becker" American Neoliberalism and Michel Foucault’s 1979 Birth of Biopolitics Lectures, October 2012

615. William H. J. Hubbard, Another Look at the Eurobarometer Surveys, October 2012

616. Lee Anne Fennell, Resource Access Costs, October 2012

617. Ariel Porat, Negligence Liability for Non-Negligent Behavior, November 2012

618. William A. Birdthistle and M. Todd Henderson, Becoming the Fifth Branch, November 2012

619. David S. Evans and Elisa V. Mariscal, The Role of Keyword Advertisign in Competition among Rival Brands, November 2012

620. Rosa M. Abrantes-Metz and David S. Evans, Replacing the LIBOR with a Transparent and Reliable Index of interbank Borrowing: Comments on the Wheatley Review of LIBOR Initial Discussion Paper, November 2012

621. Reid Thompson and David Weisbach, Attributes of Ownership, November 2012

622. Eric A. Posner, Balance-of-Powers Arguments and the Structural Constitution, November 2012

623. David S. Evans and Richard Schmalensee, The Antitrust Analysis of Multi-Sided Platform Businesses, December 2012

624. James Melton, Zachary Elkins, Tom Ginsburg, and Kalev Leetaru, On the Interpretability of Law: Lessons from the Decoding of National Constitutions, December 2012

625. Jonathan S. Masur and Eric A. Posner, Unemployment and Regulatory Policy, December 2012 